\title{
Review of the theoretical underpinnings in the creative tourism research field
}

\section{Revisão dos fundamentos teóricos no campo de pesquisa do turismo criativo}

\author{
Rui Miguel Ferreira Carvalho \\ University of Aveiro, member of the tourism research group of the research unit on Governance, Competitiveness and Public \\ Policies (GOVCOPP), r.carvalho@ua.pt
}

Carlos Manuel Martins da Costa

University of Aveiro, Portugal, head of the tourism research group of the research unit on Governance, Competitiveness and Public Policies (GOVCOPP), ccosta@ua.pt

Ana Maria Alves Pedro Ferreira

University of Évora, Research Assistant at the Research Centre for Spatial and Organizational Dynamics, amferreira@uevora.pt

\begin{abstract}
Despite the rising number of creative tourism publications, creative tourism is still emerging as a recent research area. Its study ranges from urban cities to rural areas implicating different uses for creativity, culture, events, creative networks and the co-creation of experiences. This paper had the goal to focus on the main theoretical subjects of creative tourism as a research area. As a result, the authors pinpoint vital issues present in creative tourism literature even though its definition is still evolving. After a thorough literature review, the authors conceptualised three main theoretical contributions present in creative tourism literature: 1 ) creativity and its relation to tourism, (2) specialised consumption as a characteristic of the postmodern tourist and 3 ) the experience economy paradigm and co-creation. This study identifies the main theoretical underpinnings of creative tourism, which made this special interest tourism gain so much importance in recent years.
\end{abstract}

Keywords: Creative tourism, creativity, specialized consumption, experience economy and co-creation.

\section{Resumo}

Apesar do crescente número de publicações sobre turismo criativo, este tipo de turismo ainda está emergindo como uma área de pesquisa recente. O seu estudo abrange as cidades urbanas e áreas rurais implicando diferentes usos para a criatividade, cultura, eventos, redes criativas e a cocriação de experiências. Este artigo teve como objetivo focar os principais temas teóricos do turismo criativo como área de pesquisa. Como resultado, os autores apontam questões-chave presentes na literatura do turismo criativo, embora a sua definição ainda esteja a evoluir. Após uma revisão minuciosa da literatura, os autores conceptualizaram três principais contribuições teóricas presentes na literatura do turismo criativo: 1) criatividade e sua relação com o turismo, (2) o consumo especializado como uma característica do turista pós-moderno e 3) o paradigma da economia da experiência e da cocriação. Este estudo identifica os principais fundamentos teóricos do turismo criativo, o que fez com que este tipo de turismo ganhasse tanta importância nos últimos anos.

Palavras-chave: Turismo criativo, Criatividade, Consumo especializado, Economia da experiência e co-criação.

\section{Introduction}

A serious approach to the study of creative tourism must contemplate its origins and the main reasons for its development. This paper intends to discern emerging theories from the growing number of publications about creative tourism; undertaken in recent years (Maldonado-Erazo, Álvarez-Garcia, \& del Río-Rama, 2016) thus contributing to the establishment of creative tourism as an emergent area of research (Richards, 2011). As a form of postmodern tourism consumption (Molina, 2016), its concept has been evolving throughout the years (Smith, 2016). This subject has been analysed in different ways, mainly from the supply side (Tan, Kung, \& Luh, 2013) with several theoretical examples (ex: Binkhorst \& Den Dekker, 2009; Carvalho, 2014; Richards, 2003, 2011; Richards \& Marques, 2012; Richards \& Wilson, 2006, 2007; Salman \& Uygur, 2010) and more pragmatic approaches (e.g. Brunner, 2016; Carvalho, Costa, \& Ferreira, 2015; Carvalho, Ferreira, \& Figueira, 2011; Tan et al., 2013; Tan, Luh \& Kung, 2014), among many others.

A detailed reading of the main works on creative tourism will show special attention to changes in consumer's choices coinciding with post-modern (Thompson, 2000) forms of cultural consumption in tourism, creative industries and the role of the ICT. Here, specific issues have been receiving more attention from research, including: cocreation (Binkhorst \& Den Dekker, 2009); creative tourism and the creative industries (Campbell, 2011; Marques \& Borba, 2017) products, services and experiences design (Richards, 2016; Richards \& Wilson, 2006); authenticity and local uniqueness in creative events (Carvalho et al., 2015, 2011, Richards, 2010a, 2015b); the necessity for skills development on the supply and demand sides as the development of cultural capital (Carvalho, 2014; Richards \& Wilson, 2006, 2007); the impact of cultural industries on tourism (Richards, 2012; Smith, 2016) and the role of new intermediaries in creative tourism (Carvalho, Costa, \& Ferreira, 2018; Richards, 2016) among others.

In this review paper, the purpose of the authors was to show the path of creative tourism research as well as to integrate and summarise what is known (Jennings, 2010; Neuman, 2006). Following several theoretical perspectives, the authors have identified key contributions in creative tourism literature following much of the work of one of the co-founders of the concept, Greg Richards. A very prolific researcher, Richards has been developing this concept and constitutes one of its principal authors along with others. Following their work, the authors identified three main 
areas in creative tourism research, which can arguably be defined as follows: 1) creativity and its relation/application to tourism, (2) specialised consumption as a characteristic of the postmodern tourist and 3) the experience economy paradigm and co-creation.

The goal of this paper is to pinpoint these themes, their main contributions to the development of creative tourism as well as their applications and connections to new and broader issues in tourism like sustainability and territorial authenticity (Citarella \& Maglio, 2014; Korez-Vide, 2013; Molina, 2016; Ohridska-Olson \& Ivanov, 2010) and new cultural and tourism intermediaries as well as cultural capital development (Carvalho, 2014; Carvalho, Costa \& Ferreira, 2018).

\section{Creative tourism - the genesis of its conceptual evolution}

According to Richards, (2009, p.78) "the roots of the creative tourism concept go back to the mid-1990s when a group of researchers and practitioners were looking at ways to enhance the sales of craft products to tourists (...) through the project EUROTEX (Richards, 2009). The innovation consisted of bringing tourists closer to the production process through the observation of artisans' work or for tourists to learn some production techniques for themselves (Richards, 2009). Although creative tourism is a recent area of study, there are some examples despite the scarce literature reviews carried out in the field of creativity and tourism (Richards, 2011), creativity, tourism and cities (Richards, 2013b) and cultural capital in the field of creative tourism (Carvalho, 2014; Carvalho et al., 2018). It is possible to verify that the growth in the number of publications about creative tourism happened in 2012, according to the Scopus database (Maldonado-Erazo et al., 2016).
According to Maldonado-Erazo et al., (2016), "specific terms such as "creative cities" (Akerlund \& Muller, 2012, Catungal, Leslie \& Hii, 2009, Martinez, Meroz \& Serulus, 2013), "creative industries" (Campbell, 2015, Chang, Backman \& Huang, 2014, Chao, Shyr, Lee, Chao, Tsai \& Kang (2013), "creative tourists" (Ali, Ryu \& Hussain., 2015, Ngamsirijit, 2015, Tan, Luh \& Kung, 2014) even "creative employees" (Brouder, 2013, Guano, 2015, Horng, Tsai, Liu \& Chung) have led to the consolidation of this relationship [creativity and tourism] under the name of creative tourism" (MaldonadoErazo et al., 2016, p. 84). However, the term "creative class" of Florida (2002, 2007), is also referred to by Richards, (2011) when citing the work of Stolarick, Denstedt, Donald \& Spencer, (2010) concerning creative tourism. "Creative tourism is here to be developed as a typology of creative class strategy [in the context of increasing visitors to Prince Edward County in Canada]" (Richards, 2011, pp 1241-1242).

Analysing important examples from the creative tourism literature (e.g. Binkhorst \& Den Dekker, 2009; Maldonado-Erazo et al., 2016; Marques \& Richards, 2014; Molina, 2016; Richards, 2003, 2009, 2011, 2012, 2014, 2016; Richards \& Marques, 2012; Richards \& Wilson, 2006, 2007; Smith, 2016) we can trace the emergence of creative tourism as an extension or reaction to cultural tourism, (King, 2009). "Creative tourism was first mentioned as a potential form of tourism by Pearce and Butler (1993), although they did not define the term" (Richards, 2011, p. 1237). Despite this, we have mapped the evolution of its concept (Dubru, 2009, Richards \& Raymond 2000, UNESCO, 2006, Virginija, 2016) and also new conceptions based on creative industries (OECD, 2014; Richards, 2012; Smith, 2016) were summarised in table 1.

Table 1 - Evolution of the concept of creative tourism

\begin{tabular}{|c|c|}
\hline Author & Definition \\
\hline $\begin{array}{l}\text { Maldonado-Erazo et al., } \\
\text { (2016) referring to } \\
\text { Pearce \& Butler, (1993) }\end{array}$ & $\begin{array}{l}\text { "They establish the main foundations of tourism motivation based on a pre- and post-evaluation model of the } \\
\text { psychological impact that tourism development has within a locality highlighting among them the creativity of the } \\
\text { activities carried out". }\end{array}$ \\
\hline $\begin{array}{l}\text { Richards \& Raymond } \\
(2000)\end{array}$ & $\begin{array}{l}\text { "Tourism, which offers visitors the opportunity to develop their creative potential through active participation in } \\
\text { courses and learning experiences, which are characteristic of the holiday destination where they are undertaken". }\end{array}$ \\
\hline UNESCO (2006) & $\begin{array}{l}\text { "Creative tourism involves more interaction, in which the visitor has an educational, emotional, social, and } \\
\text { participative interaction with the place, its living culture, and the people who live there. They feel like a citizen". }\end{array}$ \\
\hline Raymond, (2007) & $\begin{array}{l}\text { Creative Tourism New Zealand: creative tourism is "A more sustainable form of tourism that provides an authentic } \\
\text { feel for a local culture through informal, hands-on workshops and creative experiences. Workshops take place in } \\
\text { small groups at tutors' homes and places of work; they allow visitors to explore their creativity while getting closer } \\
\text { to local people." }\end{array}$ \\
\hline DuBru, (2009) & $\begin{array}{l}\text { "Creative tourism is travel directed toward an engaged and authentic experience, with participative learning in the } \\
\text { arts, heritage, or special character of place and it provides a connection to those who reside in this place and who } \\
\text { help to create this living culture". }\end{array}$ \\
\hline $\begin{array}{l}\text { (Smith, } 2 \\
\text { 206) }\end{array}$ & $\begin{array}{l}\text { Creative tourism can include: a) Place-based creative activities such as: "cookery, winemaking, painting, drawing, } \\
\text { photography, wood or stone carving, pottery, sculpture, crafts, flower arranging, drama, music, dance" (Smith, } \\
\text { 2016, p. 203); } \\
\text { b) Creative tourism can be defined as "exploring and expressing one's creative potential whilst on holiday. The activities } \\
\text { and the relationship to the self are the primary focus; context or setting is secondary" (Smith, 2016, p. 204); } \\
\text { c) Finally creative tourism can be "closely connected to earlier discussions about creative industries: enjoying } \\
\text { attractions and activities which are linked with creative industries, and which tend to be interactive or experiential } \\
\text { in nature (...) such as film and TV, fashion, design and architecture" (Smith, 2016, pp. 205-206). }\end{array}$ \\
\hline
\end{tabular}

Source: Authors based on (Dubru, 2009; Maldonado-Erazo et al., 2016; OECD, 2014; Pearce \& Butler, 1993; Raymond, 2007; Richards \& Raymond, 2000; Smith, 2016; Unesco, 2006; Virginija, 2016). 
Richards \& Raymond's, (2000) "original" definition is highly cited in creative tourism literature, primarily based on creative experiences whose main concern was the pragmatic involvement of the tourist through the organisation of art related activities. "Early creative tourism concepts were based on learning experiences related to traditional areas of culture and creativity. More recent models have been based on the integration of the tourism and creative industries as a whole, engaging not only consumers [mediators, intermediators, cultural brokers] but also producers, policy makers and knowledge institutions" (OECD, 2014, p. 16). According to Richards \& Wilson, (2007), the definition of creative tourism has several implications such as the development of the creative potential of tourists; the active involvement of the tourist; personal experiences of the chosen destination and co-creation as a process of production of products, services and experiences.

Recently the definition of creative tourism has become a label for concepts such as economic, cultural, social and environmental sustainability, slow tourism and valorisation of the local community, the personal development of the tourist and the reflexivity of tourism social agents. If the first definitions of creative tourism enhance practical experiences, UNESCO's definition reinforces its potential as a model for territorial development at an international level. As DuBru, (2009) emphasises the connection of creative tourism to local communities, Virginija, (2016) emphasises Raymond's opinion of participation and informal communications between tourists and local communities (Virginija, 2016).

This way, the development of experiences in the context of creative tourism (Richards, 2016) has evolved from more or less participative experiences to "hands-on" experiences (Brunner, 2016). Many workshops were added to creative events as new forms of engaging with locals, adding value to personal experiences, and helping to diversify the tourism offer of various tourist destinations (e.g. Carvalho et al., 2011).

According to Smith, (2016), the definition of creative tourism has evolved from more basic experiences to experiences powered by the so-called cultural and creative industries (e.g. Marques \& Borba, 2017). The author explains that creative tourism may incorporate up to three definitions as summarised in the box above. "Three possible definitions [are suggested] the first implies going to the "home" of a certain creative activity, whether it be crafts, dance, cookery or music, and engaging with local people and culture(s); the second definition means that visitors can undertake creative activities, but these may be in environments where the location is largely incidental, and there is little or no contact with local people; third, creative tourism can involve the enjoyment of creative industries such as architecture, film, fashion or design"(Smith, 2016, p. 209).

Several facts led to the development of creative tourism as an alternative to mass forms of tourism consumption surpassing what Poon, (1993) called "new tourism". Because creative tourists want the real thing, tourism supply changed to connect personalised products, services and experiences to tourists better. Arguably, creative tourism represents this paradigm shift. "Whereas cultural tourism was traditionally seen as a rather passive form of consumption, whereby tourists enjoyed heritage sites or artistic spectacles, creative tourism is about more interactive forms of activity which are closely linked to either to a location and its people or to some of the more technologically advanced industries" (Smith, 2016, p. 189). Creative tourism literature is useful in directing cultural tourism, as the type of tourism which has triggered this change, be it for its massive consumption by tourists, liberalization of the tourism sector, social and cultural changes in the tourism sector (e.g. King, 2009; Richards, 2011, 2014b) or the reflexive postmodern tourist.

Several reasons contributed to this paradigm shift: the massification of cultural tourism consumption and the monotony of tourism experiences: the serial reproduction of cultural products, tourism destinations vis-à-vis globalisation effects and product standardisation in the tourism sector; the necessity for specialised consumption and new tourism segments (Lash, 1990; Munt, 1994; Richards \& Wilson, 2006, 2007) made possible by the growth of scholarly and more aware consumers as they are involved in both processes of production and consumption (co-creation); and their will to engage with local communities and live like locals (Smith, 2016). These factors have contributed to the diversification of cultural resources, the particular interest in the everyday culture of the destination in detriment of high culture associated with cultural tourism (Bourdieu \& Darbel, 2003) and a higher prevalence for customised tourist experiences which are configurative of personal meaning, offering the possibility to add something to the subjective narratives of postmodernity (adapted from Richards, 2013c, 2011, Richards \& Wilson, 2006, 2007).

According to the literature review, it is not possible to think about creative tourism without referring to cultural tourism, since the latter did not disappear (King, 2009). It contributes to creative tourism being seen as "the next generation of cultural tourism that satisfies the higher-level need of selfactualisation with a primary focus of active skill development" (Ohridska-Olson \& Ivanov, 2010, p. 2). Having this in mind and after consulting several examples of creative tourism literature, the authors present three main theoretical underpinnings of creative tourism literature highlighted in table 2: 
Table 2 - Emerging theories in the creative tourism research field

\section{Creativity and Tourism}

Cultural industry (Adorno, 2002), Creative industries (DCMS, 1998, 2004); Creative City (Landry, 2000) and Creative Class (Florida, 2002, 2007); Creative clusters (Evans, 2009) and Ethnic enclaves, (Shaw, 2007) cited by Richards (2011); "Global districts", Cultural clusters, cultural quarters (Zukin, 2004) cited by Richards and Wilson, 2006, 2007); (Smith, 2016).

\section{Specialised consumption}

Specialised consumption (Scitovksy, 1976, 1992); Prosumer (Toffler, 1980); Reflexive modernity and narrative of the Self (Giddens, 1991) cited by (Richards, 2009, 2011), Postmodern consumer/consumption (Thompson, 2000), authenticity, Wang, 1999).

\section{Experience economy and co-creation}

Experience economy (Pine and Gilmore, 1998, 1999); (Anderson, 2007); Flow experience (Csíkszentmihályi, 1992, 2002); Experiential marketing (Schmitt, 1999); Cocreation process (Prahalad e Ramaswamy, 2003, 2004); (Binkhorst, 2007); (Binkhorst e Den Dekker, 2009) cited by (Richards, 2009, 2010, 2011); (Richards and Wilson, 2006, 2007); (Smith, 2016).

Authors: based on (Binkhorst, 2008; Binkhorst \& Den Dekker, 2009; Maldonado-Erazo et al., 2016; Richards, 2009, 2013c, 2011, 2012, Richards \& Wilson, 2006, 2007; Smith, 2016).

It is possible to identify the same subjects in creative tourism literature: a growing importance of creative inputs in the tourism sector from destinations and enterprises to tourists and local communities; the characteristics of the postmodern tourist as specialized consumption provides meaning, challenges, and the "craving" for co-created experiences where the tourist plays an essential role on both sides of demand and supply. Arguably, in identifying these pathways, the authors point out the reasons for the development of this type of tourism but also the implications for the innovations undergone by the creative tourism sector regarding supply and demand strategy development, business models, destination imaging, territorial marketing, creativity inputs and tourism consumption. The next subsection addresses these matters in a more detailed way.

\section{Creativity and tourism - a useful relationship}

The importance of creativity in the development of tourism products, services and experiences has been crucial for creative tourism. Although literature concerning creativity in tourism is scarce, authors focus on destinations, spaces and cities (Ravar \& lorgulescu, 2014). Central to the discussion of creativity and tourism is the significant role that culture plays in the economy, in territories and destinations. Richards \& Wilson, (2007) argue that culture and creativity are different; the first one is rooted in the past and the latter a synonym for skills, talent, and exploring the intellectual property. For example, according to the Frankfurt School, culture was described as unchallenging and pacifying consumers into becoming unthinking (Smith, 2016). In more recent economy contexts, culture assumes a vital role in the development of territories.

Rhodes, (1961) develops the four Ps of creativity: The creative product, as a new, different and original element; the creative process as a step which originates the construction of new ideas; the creative person as the one who executes the idea with skills and personality traits and the creative press or environment, the space where creativity is born. Comella, (1989) states that creativity is a process with four phases: 1 mental activity which runs through a central map where it is initiated, 2 by identifying problems, which it intends to resolve through 3 original solutions that can be 4 applied immediately in order to solve problems. Finally the United Nations (2008) "provides two perspectives on creativity: on the one hand, creativity means formulating new ideas and applying them to produce original works of art and cultural products, functional creations, scientific inventions and technological innovations; on the other hand, creativity also refers to an inner characteristic of individuals to be imaginative and to express ideas which ultimately represent the essence of intellectual capital" (Ravar \& lorgulescu, 2014, p. 256).

Briefly, creativity is multifaceted and can vary according to the areas where it is applied. It can be characterised as a process or strategy with the goal to resolve problems or the improvement of products, processes, services or experiences when applied to management, quality management, and people, among others. According to Richards \& Wilson, (2007) the 'creative turn' in the social sciences developed out of the earlier 'cultural turn' as broadening notions of 'culture' began to undermine the explanatory power of the term, and as 'culture' itself waned in terms of its ability to generate distinction for social groups, economic classes and places. According to Jelincic, $(2009$, p. 259) "these changes reflect also the sector of tourism, which is obvious in the evergrowing splintering of tourism market as well as of tourism forms". In the end what the authors point out; in this creativity discourse is that it allowed the development of consumption alternatives in cultural tourism, giving rise to strong and lasting impacts for supply and demand imposing news ways to consume and relate to one another in the tourism context.

Creativity had the goal to resolve several problems of massified forms of tourism consumption (resort package products, all-inclusive in the sea, sun and sand and cultural tourism typologies), contributing to the offering of differentiating experiences, a greater segmentation of the touristic market (Poon, 1993) and corresponding to the appeals of the postmodern consumer (Thompson, 2000). The 
merge between culture and tourism has allowed the differentiation of experiences based on the culture of the destination where monuments and museums used to mark tourism tours. Richards, (2012) informs us that creativity has been applied to tourism in many different ways such as tourism products and experiences, the revitalisation of existing products and the valorisation of cultural and creative assets. Creativity provides economic spin-offs for creative development, the use of creative techniques to enhance the tourism experience and the creation of buzz and atmosphere.

Creativity discourse in tourism is also linked to cultural and creative industries, creative cities and the creative class (Richards, 2013b) but also to the creative economy. Since Adorno and Horkheimer (O'Connor, 2010) and the Frankfurt School, the notion of the cultural industry has influenced culture and creativity as a means to develop cities. Crucial to the discussion of creativity and creative tourism is Florida $(2002,2007)$ who considers human creativity as the basis for economic advantages and a factor of economic growth (Maldonado-Erazo et al., 2016; Richards, 2011). The concept of creativity present in the theories of the creative class and creative cities will give rise to various discussions about the success or failure of cultural policies, tourists and workers mobility, (Gornostaeva \& Campbell, 2012; Raunig, Ray, \& Wuggenig, 2011) and the differentiation of urban venues in a globalized and tourism contexts (Pappalepore, Maitland, \& Smith, 2010, 2014). So, it was no surprise that the study of tourism and the creative industries increased (Smith, 2016).

For example, cities could prosper if they could attract creatives and talented people. They would embody the socalled creative class, corresponding to the "petit bourgeoisie" of Bourdieu, (1979). At the time of "Distinction", this class was too young, already demonstrating a taste for new forms of international culture and may be at a central position today (Prieur \& Savage, 2011). "We can see this shift as associated with the institutions of the cultural industries, through the marketing of novel cultural forms, as well as the concern of cultural institutions such as museums and art galleries to emphasise temporary exhibitions to bring in new audiences" (Prieur \& Savage, 2011, p. 578). This opinion converges with Smith, (2016) where she refers to the postmodern theory in the strategy of more inclusive policies, privatisation of industries and the decline of state cultural subsidies.

The creative use of culture allowed for the development of cultural resources, cities, territories and tourism destinations. This reflected politicians' choices that challenged the public and private sectors. Public policies based on the creative industries are also developed in several forms: creative areas, cultural quarters, creative districts, creative clusters (Hitters \& Richards, 2002); (Pappalepore et al., 2010, 2014), (Ferreira \& Costa, 2001, 2006). Despite "gathering" cultural resources and installations for cultural fruition, these areas mirrored
Porter, (1990); and the tendency for the creative class to fixate on certain city areas (Richards, 2011).

Following creativity gurus Florida and Landry, many regions understood creativity as a means to revitalise cities and historical centres, attract new enterprises, improve quality of life, create jobs and boost tourism numbers (Richards, 2012, 2013). In an attempt to differentiate tourism destinations, similar strategies were followed: iconic structures, megaevents, thematisation of cultural routes and heritage mining (Richards, 2013c; Richards \& Wilson, 2006, 2007). Criticism of the use of creativity and cultural industries mainly in urban areas originated heated discussion around precarious work conditions of creative workers (Gornostaeva \& Campbell, 2012), devaluation of culture (Raunig et al., 2011), gentrification (Pratt, 2008), serial reproduction of culture (Richards \& Wilson, 2006, 2007), unsustainability of urban policies and creative models (Evans, 2009), among many others.

Richards, (2013) points to five changes in the relation between creativity and tourism: a) The basis of cultural economy (from a policy of subsidising high culture, to cultural dissemination supported by the creative industries to the emergence of a co-created cultural model) (e.g. Ferreira, 2010; Potts, Cunningham, Hartley, \& Ormerod, 2008) b) a fundamental change from heritage and cultural resources based experiences to symbolic and intangible means of cultural fruition (Richards, 2011); c) the evolution of individual creativity to more collective forms of knowledge creation (e.g. Potts et al., 2008); d) the incorporation of cultural and creative elements into the tourism product of cities which is becoming increasingly embedded in the everyday life of cities (Richards, 2011) and finally (e) the creation of new creative areas and environments in cities and the development of new creative clusters (Pappalepore et al., 2010, 2014). Other factors contributed to changes in the way tourists consume tourism in the light of postmodern tourism consumption through a myriad of choices.

\section{The importance of specialised consumption in creative tourism}

In order to understand the origins of creative tourism, one needs first to look at the rise of culture as a form of tourism consumption (Richards, 2013c). The characteristics of tourism's current consumption demonstrate that it has increasingly acquired a diverse, multidimensional and (micro) segmented character, corresponding to broader use of culture already mentioned in the previous section (Jelincic, 2009). According to Richards, (2016), three basic forms of tourism consumption have been identified in tourism literature: the development of specialised consumption, the growth of the experience economy and increasing fragmentation of consumer markets. 
More active than passive consumption options; stand out from the previously standardised consumption (e.g. cultural tourism) which was not so differentiated to a more culturally diverse and multiform type of tourism (e.g. creative tourism). In this context, specialised consumption refers to the development of new skills through new challenges in tourism consumption. "Where activities require a high level of skill or give opportunities to learn new skills, participants continue to search for stimulation through repeated experiences as new challenges emerge and skill levels rise" (Richards, 1996, p. 25). Stimulation, excitement and skill development are entwined in the generative principle of creative tourism. Nonetheless, Munt (1994) already referred to new forms of tourism consumption.

Discussion around the specialised consumption refers to the increasing involvement of the consumer in the act of consuming and skill development. In this context two issues emerge: the relationship between producer and the produced good (in touristic terms, the touristic product, service or experience) and the development of skills by consumers through co-creation or '"prosumption' as the process by which the consumer becomes a producer of the products and experiences they consume" (Richards, 2013, p. 299). The first issue is addressed under the lens of Benjamin, (2008) and the second one follows the arguments of Scitovksi, (1976) present in (Bianchi, 2003; Richards, 2009, 2013, Richards \& Wilson, 2006, 2007).

Preoccupied with the standardisation of cultural production and its fruition, the leading figures of the Frankfurt School (Horkheimer, Adorno, Marcuse and others) developed work in these areas through critical theory (Assoun, 1989). Alienation in production and consumption moments was one of the subjects that connect to the need for specialised consumption. In an article entitled "The Work of Art in the Age of Its Technological Reproducibility", Benjamin; (2008); criticises the standardised forms of production and reproduction of cultural goods referring to the loss of its aura, "hic et nunc" or "here and now" at the moment of production. "That is its genuineness. The genuineness of a thing is the quintessence of everything about it since its creation that can be handed down, from its material duration to the historical witness that it bears" (Benjamin, 2008, p. 7).“The present decadence of the aura appears as the major symptom of mass culture: it is the need for proximity and possession that tends to depreciate the character of what is not given only once through standardization" (Assoun, 1989, p. 108).

If the cultural industry (Adorno, 2002) caused alienation during cultural production with profound impacts on cultural consumption, the massive consumption of cultural goods surpassed other spheres of social life and arguably tourism. "Authors such as Cohen (1972, 1979, 1988), Lengkeek (1994, 1996), MacCannell (1976) and Urry (1990) all interpret tourism as a consequence of the alienation in everyday life"
(Binkhorst, 2007, p. 127). One cannot dissociate alienation in the moments of consumption and production from the classical works of Debord's the "Society of the spectacle" and Marcuse's "One-dimensional man" in the Frankfurt School of Critical Theory on culture and aesthetics (Best, Bonefeld, \& O'Kane, 2018). The authors link these classical works to the discussion of specialised consumption not because they are comparing tourism consumption to the consumption of mere art goods but because its criticism points to the banality of culture consumption pointed out in creative tourism literature and the context of post-modernity.

"The reproducible work of art loses its value as a "cultural object" to its value as a reality to be exhibited (...) as the social significance of an art diminishes, the public is witnessed by a growing divorce between the critical spirit and the conduct of pleasure" (Assoun, 1989, p. 108). Far from addressing the social and political consequences of the critic of Benjamin and others, this discussion is important in the context of the homogeneity of cultural goods and its fruition by the public. The authors find some similar problems in creative tourism literature where massified forms of cultural tourism are addressed. Cultural tourism products present in massified tourism destinations are identical, where the tourist can contemplate the "must see" places like monuments, museums, cultural routes, mandatory cultural itineraries or cultural circuits, making sure that a picture proves one has indeed been there (Richards, 2009, 2013c; Richards \& Wilson, 2007). This makes way for what Richards \& Wilson, (2006) coined as "The serial reproduction of culture".

Massification of cultural goods, the development of ICT, the advent of the internet and globalisation markets gave rise to the exaggeration of external stimuli as marketing and publicity and internal ones such as the postmodern individualism. Rapidly, several authors identified changes in consumption and consumer characteristics. Toffler's "prosumer" related to a more attentive and demanding consumer, able to approach the supply side and influence the design of new products, contributed to the "disappearance" of the "simple" relation between production and consumption sides. It becomes possible to exalt individualisation (Lipovetsky, 1983) through a personalised and hedonistic consumption, characteristics of the postmodern condition (e.g. Lyotard, 1989) and the postmodern consumer (Thompson, 2000), in an attempt to react to mass production and consumption of cultural goods. Here we find the influence of new forms of consumption and segments in tourism (Poon, 1993).

On the other hand, specialised consumption, according to Richards, (2003) refers to the need for self-creation in the context of leisure with implications for creativity and tourism (Richards, 2011). Arguably, the authors relate the need of selfdevelopment, identity construction or narrative of the Self (Giddens, 1991) to the philosophical existentialist theories of 
"self" and the "other" (Lanfant, 1995 cited by Smith, 2016) with old implications for the study of tourism (e.g. Urry, 2002). "The current movement of society is towards specialized consumption, including education, self-development, and creative activities that depend on the developing of individual skills and creativity" (Richards, 2009, p. 80). The skilled consumer often knows more about the experiences they are consuming than the people who are supposed to supply them. Not surprisingly, therefore, skilled consumers have begun to take the lead in experience production (Richards, 2013c).

According to Richards, (2009), skilled consumption under Scitovksy's (1976) own designation refers to the fact that people are no longer just concerned with accumulating goods, but they also want to develop themselves and their consumption skills. Consumers know what they are doing and are doing the best they can, and as a consequence, preferences can be inferred from choices made (Bianchi, 2003.) Scitovksy asks this simple question: Why isn't consumption satisfactory to every consumer? According to Bianchi, (2003), Scitovsky found three conflicts between choices and preferences (comfort vs pleasure; standardised goods vs goods and individual desires and finally specialised consumption and general skills). Scitovsky (1972) states that a lack of consumption skills has to do with the type of education consumers receive [e.g. Bourdieu, 1979]. Though access to education has long ceased to be restricted to an elite, he argued, its nature has changed, liberal arts having being replaced by professional training and specialised production skills (Bianchi, 2003; Scitovsky, 1972). The authors of this chapter perceive specialised consumption as the creative involvement of the tourist in the process of both production and consumption of cultural goods, products, services and experiences. In connection to creative tourism, it is important to know "what makes creative activities so pleasurable - is that these activities, because of the skills they require, their complexity and variety, and their separateness from mere need, can be a constant source of novelty and change" (Bianchi, 2003, p. 8). That is what creative tourism is all about, developing new skills and wanting something new and different. "In essence, the creative tourist is the prototypical "prosumer", engaged in a combination of skilled consumption and skilled production" (Richards \& Wilson, 2006, p. 1220). This not only implies cocreation (Prahalad \& Ramaswamy, 2004) as a fundamental factor for creative tourism success but also the development of (inter) cultural capital (Bourdieu, 1986, 2010; Carvalho, 2014; Pöllmann, 2013) as an essential characteristic of postmodern consumers (Thompson, 2000).

Arguably, the concept of specialised consumption in creative tourism implies a change from the forms of external distinctions prevalent in cultural tourism to more internal forms of distinction based in a model characterised by the development of skills and experiences. The authors highlighted specialized consumption as one of the leading theories of creative tourism literature by linking it to postmodernity consumption (discontinuity between high and low culture; the need for skill development for both sides of supply and demand; the new role of a more active and questioning consumer, new business models, among others). The seminal work of Pine and Gilmore, (1998) revolutionised the business world with severe implications for tourism as experiences became central in the travelling sector and with a particular incidence in creative tourism. On the other hand, co-creation (Binkhorst, 2007; Binkhorst \& Den Dekker, 2009; Prahalad \& Ramaswamy, 2003, 2004) became the primary process through which creative tourists can engage in meaningful and memorable touristic experiences.

\section{Experience economy and co-creation in creative tourism}

The experience discourse in the late nineties brought a new look over consumption, new consumer profiles and interests, contaminating tourism. "The context of this concept is an unabashed updating of the economic liberalism of Smith (1776), with the starting premise that in the beginning economies developed around the sale of commodities with an emphasis on selling goods cheaply. However, as industrialisation deepened, this not only became harder but had initiated a kind of 'race to the bottom' and new ways were sought to differentiate commodities and goods from their competitors with the advent of an attached service" (Willett, 2009 , p. 2). "The buzz- word "experience economy" was developed because markets were saturated, and since consumer consumption patterns changed, service providers found it necessary as a new marketing strategy to ensure customer satisfaction and loyalty" (Ali, Ryu, \& Hussain, 2016, pp85-86). The authors argued that more or less active experiences could be developed depending on the immersion or absorption of consumers.

Creative tourism literature mentions the staging of experiences (Pine \& Gilmore, 1998) as central to differentiating touristic products and destinations although later there was particular emphasis on co-creation processes (Binkhorst, 2005; Prahalad \& Ramaswamy, 2003, 2004). However, experience staging rapidly bored tourists creating the necessity to innovate the experience market. Richards (2016) sums up two types of experiences. Pine \& Gilmore, (1998)"first generation experiences are criticised for being too staged, commercial and artificial and therefore not suitable to today's customers" (Boswijk et al., 2005)."The "second generation" of experiences that emerged around the turn of the Millennium were therefore based on co-creation between company and client, enabling customer-driven product development, and, in the context of tourism, more meaningful encounters between tourists and their hosts (e.g. Binkhorst, 2007)" (Richards, 2016, p. 3).

If the process of co-creation (Prahalad \& Ramaswamy, 2004) confuses the direct link between supply and demand, the 
third generation of experiences emerged, generated by communities of producers and consumers where prior differences in roles have disappeared (Boswijk et al., 2005; Richards, 2011). The experience economy discourse in tourism literature has been strongly influenced by marketing, where the co-creation of value has received several contributions (Campos et al., 2015; Rihova, 2013). Marketing of services and co-creation discourses are based in three distinct ways: a) Features and benefits (value determination category) where enterprises offer the conditions and meaning for co-creation experiences; b) value in use (service-dominant logic) where value is co-created during experiences based on consumer characteristics and c) inter-subjectivity value (customer-dominant logic) where the consumer is the only one responsible for value co-creation (Rihova, 2013).

The definition of value creation and the role of tourists in creative tourism literature is also discussed when firstgeneration experiences are suggested by several authors (Richards, 2009, 2013c, 2011, Richards \& Wilson, 2006, 2007) where gastronomy, arts, handicrafts, dance, painting, carving among many other workshops' activities are put forward, and creative enterprises and destinations need to become creative and develop skills. Later more memorable lifechanging experiences emphasising co-creation as the main component of creative tourism (Binkhorst, 2005, 2007, 2008; Binkhorst \& Den Dekker, 2009) are presented where concepts such as living "like a local" and "relational capital" are considered important for creative tourism success (Richards, 2016). In this sense, other themes are discussed in creative tourism literature connecting experiences and co-creation "Participation and knowledge of the tourist" (Richards, 2013c; Richards \& Wilson, 2006); "the active participation of the tourist" (Richards \& Marques, 2012; Tan et al., 2013; 2014) and "experience evaluation" (Binkhorst, 2007). Co-creation of experiences emerges as a fundamental process of creative tourism where all intervenients apply their knowledge influencing the experience outcome.

\section{Creative tourism development models}

The scope of creative tourism is global (Marques \& Richards, 2014; Richards, 2013, 2015a). Because of the use of intangible and renewable resources, an extensive use of cultural, creative and symbolical sources and the search for meaningful and authentic experiences, "there is a growing interest in the development of new forms of tourism that contribute to the redistribution of tourist demand in order to achieve a reduction in the levels of massification within the types of tourism consolidated in certain parts of the world, thus creative tourism is born as an alternative to such problematics" (MaldonadoErazo et al., 2016, p. p84).

Creative tourism literature is rich in indicating several business models such as Richards and Wilson's triad (Creative spaces, creative events and creative tourism activities) (2006, 2007); the use of creativity as an activity or as a backdrop, Richards (2011) or the overall creative tourism development portrayed in the OECD, (2014) report on Tourism and the creative economy (private sector-led initiatives, public sector led initiatives and public and private partnerships). According to Molina (2016), "creative tourism is not based in a unique model which can be reproducible in different environments. If creativity confers power to a place, creative tourism that works successfully in a place can fail in another with similar characteristics if simple transpositions of models occur. Creative tourism seeks the possibility for each place to structure one unique and not reproducible model" (p. 213). Besides, Richards, $(2012,2016)$ points to vehicles for cocreation in tourism and tourism development as Courses, Creative spaces, Creative Relationships, Networks and Events.

This kind of taxonomy of creative business models follows the definitions of this type of tourism. Functioning as a response or reaction to cultural tourism "creative tourism differs from traditional models of cultural tourism, primarily in being based on intangible skill and knowledge-related assets. There is evidence that these new models of creative tourism can deliver considerable added value, increasing tourism demand and diversifying tourism supply. Linking tourism and the creative industries can also aid image building, atmosphere creation and attraction of talent" (OECD, 2014, p. 51). The conditions for the models and forms of creative tourism to be developed are based on the knowledge held by both sides of supply and demand (cultural capital), in the sustainable component of resources and destinations, (Korez-Vide, 2013; Molina, 2016; Ohridska-Olson \& Ivanov, 2010) while advocating the need for new organisational forms of tourism companies, new relational forms between social agents (social capital) of the creative field of tourism and the primacy of local populations (e.g. McKercher and Du Cross, 2002) in the phases of tourism planning but also in the mediation and consumption phases of creative tourism (Molina, 2016; Richards, 2016). Private-led, public-led and public-private partnerships have been developed under creative tourism goals.

The authors thus summarise in detail the critical characteristics of the evolution of the models and forms of creative tourism present in the literature on creative tourism highlighted in Figure 1 below. Identifying creative tourism as a form of cultural tourism (Ohridska-Olson \& Ivanov, 2010), creative tourism models are based in the creative use of intangible resources, the innovative co-creation processes that seek personal development through cultural capital development and memorable experiences. Its success is based in both the private and public sector with the goal of differentiating destinations under the sustainable flag of tourism praxis. 
Figure 1 - Evolution of models and forms of creative tourism

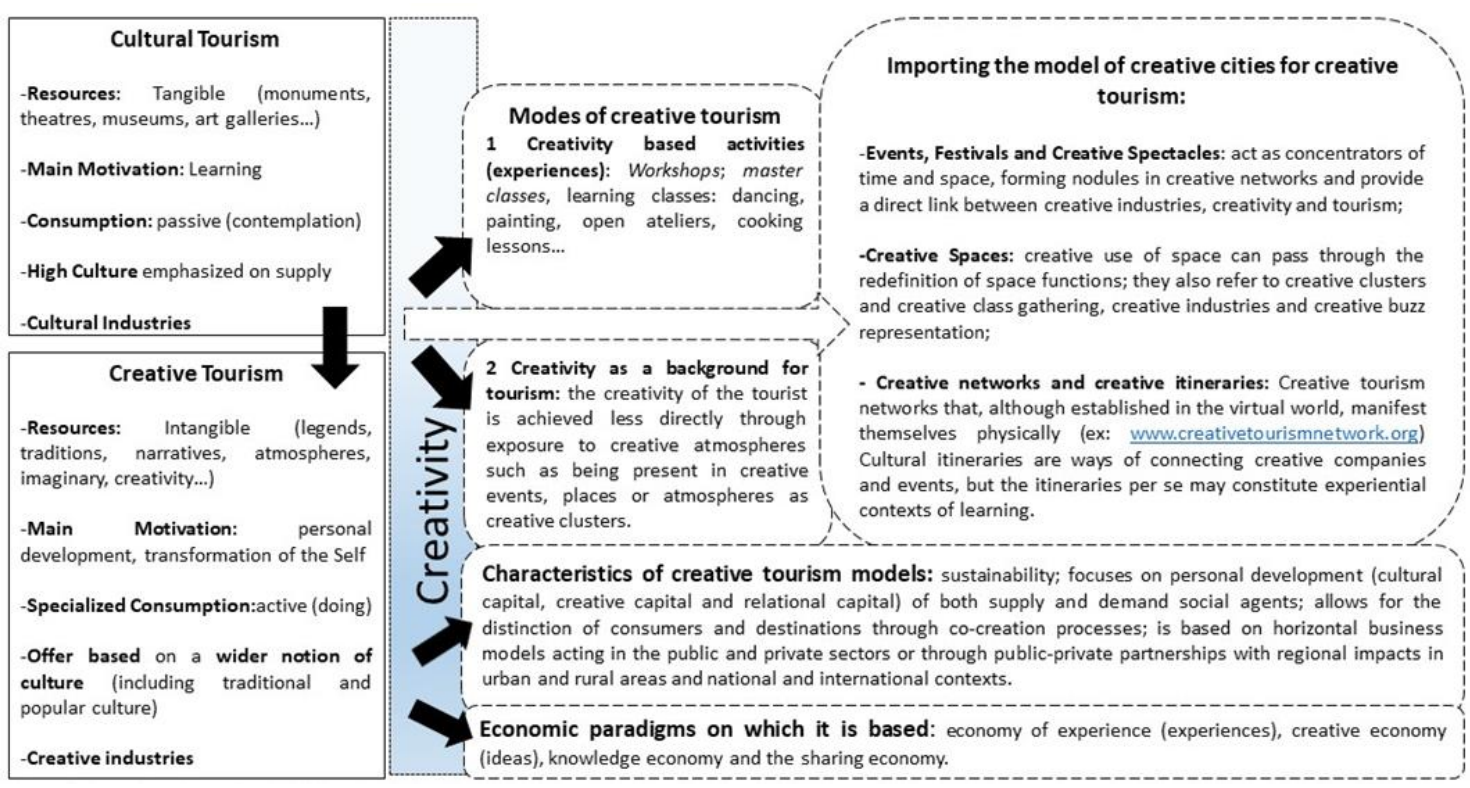

Source: Authors based on (Binkhorst, 2007, 2008; Binkhorst \& Den Dekker, 2009; Korez-Vide, 2013; Messineo, 2012; OECD, 2009, 2014; Ohridska-Olson \& Ivanov, 2010; Richards, 2009, 2013c, 2011, 2013a, 2014; 2016; Richards \& Marques, 2012; Richards \& Raymond, 2000; Richards \& Wilson, 2006, 2007; Smith, 2016; Virginija, 2016).

Creative tourism literature mentions creativity as the common denominator for this type of tourism. Based on new forms of the market approach, several examples identified by the authors manifest as more sustainable forms of tourism where creative tourism companies need to develop new skills (new organisational forms; new ways to engage with customers and other stakeholders) under the shifting characteristics of new economic paradigms. The evolution of these models and forms of creative tourism is still occurring, as more engaging ways are needed for the "new tourist" and the ever-growing presence of technology in the tourism sector.

This summary shows that the very own generating nature of this tourism niche should be considered in creative tourism research. The hybridisation of services, products and experiences is paramount for creative tourism specialised consumption. Researchers and practitioners should implement effective, sustainable principles for destinations and tourism enterprises, consider actors' reflexivity about specialised consumption, and develop horizontal based economic models and local community skill development in the co-creation of creative tourism.

\section{Conclusion}

In this research, the authors identified the main theories present in creative tourism literature, which help to understand creative tourism as a form of cultural tourism. Arguably, creativity, specialised consumption, the experience economy and co-creation theories are the underpinnings that have contributed to establishing creative tourism as a new research body. Evoking the work of previous and present authors' work, the authors hope to give a better view of the object under study for future researchers.
Underlying the importance of social, cultural and economic changes, this study has tried to link creative tourism to overall tourism studies with a particular incidence in cultural tourism studies. Based on a sociological stance, this work highlights important authors' view on these issues. The points made at various moments of this text help to establish not only connections between tourism and other social sciences but also to map links between social, cultural and economic phenomenon. New cultural intermediaries (Carvalho et al., 2018) use the internet to overcome the classic tourism economic value chain, directly contacting local community agents for tourism purposes (Richards, 2016).

For the sake of authenticity, creative tourists crave immersive, hands-on experiences which, in theory, allow tourism distinction, immersion in the destination' way of life, preventing the blasé consumption of just another touristic destination. Critical research is needed to provide reflexive and more comprehensive profiles of all the actors of the creative tourism field. Because knowledge and skills development is needed for the success of this type of tourism, how it is generated and how it is used are still questions that need serious answers. This type of tourism is based on the potential and effective use of the creativity of each destination, however, to what extent can a tourism plan, based on the principles of creative tourism, be implemented where local communities involved in tourism development, are unequally represented.

There is no doubt that creative tourism is still evolving, as are the characteristics of new consumers along with tourism market deregulation, "overtourism" impacts, sustainability issues and new cultural intermediators provided with new communication tools and increasingly relevant local 
communities in the tourism landscape. Much more research is needed around these issues as creative tourism presents itself as a valuable alternative to the serial reproduction of culture, lack of authenticity in tourism experiences, social, cultural and economic unfairness in tourism destinations.

\section{References}

Adorno, T. (2002). Indústria Cultural e Sociedade (5o edição). São Paulo, Brasil: Paz e Terra. Retrieved from http://hugoribeiro.com.br/biblioteca-digital/Industria-Cultural-eSociedade-Adorno.pdf

Ali, F., Ryu, K., \& Hussain, K. (2016). Influence of Experiences on Memories, Satisfaction and Behavioral Intentions: A Study of Creative Tourism. Journal of Travel \& Tourism Marketing, 33(1), 85-100. http://doi.org/10.1080/10548408.2015.1038418

Assoun, P. (1989). A Escola de Frankfurt. Lisboa: Editora D. Quixote.

Benjamin, W. (2008). The Work of Art in the Age of Its Technological Reproducibility. (M. W. Jennings, B. Doherty, \& T. Y. Levin, Eds.) (Vol. 39). England: Harvard University Press.

Best, B., Bonefeld, W., \& O'Kane, C. (2018). The Sage Handbook of Frankfurt School of Critical Theory. (B. Best, W. Bonefeld, \& C. O'Kane, Eds.). Sage.

Bianchi, M. (2003). A questioning economist: Tibor Scitovsky's attempt to bring joy into economics. Journal of Economic Psychology, 24(3), 391-407. http://doi.org/10.1016/S0167-4870(03)00019-9

Binkhorst, E. (2005). The co-creation tourism experience. Sitges: White Paper Co-creations.

Binkhorst, E. (2007). Creativity in tourism experiences. In Richards, G. \& Wilson (Ed.), Tourism, Creativity and Development (pp. 125-144). London, Routledge, Taylor and Francis Group.

Binkhorst, E. (2008). Turismo de co-creación, valor añadido en escenarios turísticos. Journal of Tourism Research, 1(1), 40-51.

Binkhorst, E., \& Den Dekker, T. (2009). Agenda for Co-Creation Tourism Experience Research. Journal of Hospitality Marketing \& Management, 18(2-3), 311-327. http://doi.org/10.1080/19368620802594193

Boswijk. A., Thijssen, J.P.T. and Peelen, E. (2005). A New Perspective on the Experience Economy: Meaningful Experiences. Pearson Education, Amsterdam.

Bourdieu, P. (1986). The Forms of Capital. In E. Richardson (Ed.), Handobook of Theory of Research for the Sociology of Education (pp. 46). Greenwood Press.

Bourdieu, P. (2010). A Distinção. Uma crítica social da faculdade do Juízo. Lisboa: Edições 70.

Bourdieu, P. and Darbel, A. (2003). O amor pela arte - Os museus de arte na Europa e seu público.. 2nd ed. São Paulo: Zouk.

Brunner, M. Aspects of Co-Creation in Creative Workshops 119 Customer Experience (not only) in Tourism. http://ffhoarep.fh ooe.at/bitstream/123456789/652/1/119_202_Brunner_FullPaper_en_ Final.pdf

Campbell, P. (2011). You say "creative", and i say "creative." Journal of Policy Research in Tourism, Leisure and Events, 3(1), 18-30. http://doi.org/10.1080/19407963.2011.539379

Campos, A., Mendes, J., Oom, P., \& Scott, N. (2015). Current Issues in Tourism Co-creation of tourist experiences: a literature review. Current Issues in Tourism, 1-32. http://doi.org/10.1080/13683500.2015.1081158

Carvalho, R. (2014). A literature review of the role of cultural capital in creative tourism. In J. A. C. Santos, M. Correira, M. Santos, \& F. Serra (Eds.), TMS 2014: Management Studies International Conference (pp. 17-28). http://doi.org/978-989-8472-55-7

Carvalho, R., Costa, C. and Ferreira, A. (2015). Community-based tourism festivals in the Médio Tejo Region, Portugal - A potential for the specialized cultural consumption of Creative Tourism. In: Costa, V. (Eds.) Tourism for the 21st Century - Proceedings of the CIT 2015. [online] Guimarães: IPCA, pp.291-310. Available at: http://bravo.ipca.pt/cit2015/files/ATAS_CIT_2015_FINAL.pdf [Accessed 18 Jul. 2017].

Carvalho, R., Costa, C., \& Ferreira, A. (2018). New Cultural Mediators, Cocreation, and the Cultural Consumption of Creative Tourism Experiences. In C. H. C. Ramos, P. Cardoso (Ed.), Handbook of Research on Technological Developments for Cultural Heritage and eTourism Applications (pp. 264-283). IGI Global. http://doi.org/10.4018/978-15225-2927-9.ch013

Carvalho, R., Ferreira, A., \& Figueira, L. (2011). O contributo dos eventos culturais e criativos para a criação de uma imagem diferenciadora do destino turístico maduro. o caso do festival med de loulé, algarve. Book of Proceedings Vol. I - International Conference on Tourism \& Management Studies - Algarve 2011, I, 457-466.

Citarella, G. (2014). A Systems Approach to Local Territory as a Driver for Creative Tourism Development on the Amalfi Coast. AlmaTourism Journal of Tourism, Culture and Territorial Development, (1), pp.57-80. Comella, T. (1989). Aplicación de la creatividad al planeamiento administrativo. In G. Davis \& J. Scott (Eds.), Estrategias para la creatividad (pp. 334-343). Buenos Aires: Paidós.

DuBru, N. (2009). Creative Tourism: A look at its origins, its definitions, and the creative tourism movement. In R. Wurzburguer, T. Aageson, A. Pattakos, \& S. Pratt (Eds.), A global conversation. How to provide unique creative experiences for travelers worldwide (pp. 229-237). Santa Fe: Sunstone Press.

Evans, G. (2009). Creative Cities, Creative Spaces and Urban Policy. Urban Studies, 46(5\&6), 1003-1040. http://doi.org/10.1177/0042098009103853

Ferreira, A. (2010). Comunidades criativas e desenvolvimento, Jornada - A Criatividade empresarial como Caminho para a Competitividade, Faro,Universidade do Algarve , 20 de abril, 2010.

Ferreira, A., \& Costa, C. (2001). Centros históricos e turismo. O perfil cultural dos "novos turistas" que visitaram o centro histórico de faro em 2001. Encontros Científicos, 28-46.

Ferreira, A., \& Costa, C. (2006). Novos turistas no centro histórico de Faro. Análise Social, 41(180), 767-799.

Florida, R. (2002). The Rise of the Creative Class. New York: Basic Books Florida, R. (2007). The Flight of the Creative Class. New York: Collins.

Giddens, A. (1991). As Consequências da Modernidade, 2ª edição, Ed. UNESP, São Paulo, 1991.

Gornostaeva, G., \& Campbell, N. (2012). The creative underclass in the production of place: Example of camden town in Iondon. Journal of Urban Affairs, 34(2), 169-188. http://doi.org/10.1111/j.14679906.2012.00609.x

Hitters, E., \& Richards, G. (2002). The creation and management of cultural clusters. Creativity and Innovation Management, 11(4), 234247. http://doi.org/10.1111/1467-8691.00255

Jelincic, D. A. (2009). Splintering of Tourism Market: New Appearing Forms of Cultural Tourism as a Consequence of Changes in Everyday Lives. Coll. Antropol, 33(1), 259-266.

Jennings, G. (2010). Tourism research. 2nd ed. Milton, Qld.: Wiley Australia.

King, B. (2009). "Creative tourism and cultural development: some trends and observations." Presentation at the Cultural Tourism Conference, Bonavista Institute in New Foundland, 19th November.

Korez-Vide, R. (2013). Promoting Sustainability of Tourism By Creative Tourism Development: How Far Is Slovenia? Innovative Issues and Approaches in Social Sciences, 6(1), str. 77-102. http://doi.org/10.12959/issn.1855-0541.IIASS-2013-no1-art05

Lash, S. (1990). Sociology of Postmodernism. (Routledge, Ed.). London. Lipovetsky, G. (1983). A Era do Vazio. Lisboa: Relógio D’agua.

Maldonado-Erazo, C. P., Álvarez-Garcia, J., \& del Río-Rama, M. C. (2016). Investigación Académica Internacional En Turismo Creativo. Tourism and Hospitality International Journal, 7(2), 80-106. 
Marques, L., \& Borba, C. (2017). Co-creating the city : Digital technology and creative tourism. Tourism Management Perspectives, 24, 86-93. http://doi.org/10.1016/j.tmp.2017.07.007

Marques, L., \& Richards, G. (2014). Creative Districts around the World. (L. Marques \& G. Richards, Eds.)Creative Districts (2014th ed.). Breda: NHTV, Breda.

Messineo, E. (2012). Tourist creative processes and experiences in the European Cultural Itinerary "The Phoenicians" Route'. Journal of Tourism Consumption and Practice, 4(2), 41-54.

McKercherB., du Cros, H. (2002). Cultural Tourism: The Partnership Between Tourism Tourism and Cultural Heritage Management, New York; Routledge.

Molina, S. (2016). Notas Livres TURISMO CREATIVO. Revista Turismo. Estudos e Práticas, 5, 205-223.

Munt, I. (1994). The "other" Postmodern Tourism: Culture, Travel and the new middle Class. Theory, Culture \& Society, 11, 101-123.

Neuman, W. L. (2006). Social Research Methods: Qualitative and Quantitative Approaches. Pearson Allyn \& Bacon (Sixth Edit). Boston, MA: Pearson Allyn \& Bacon.

O'Connor, J. (2010). The cultural and creative industries : a literature review [2nd ed.]. Creativity, Culture and Education Series. Creativity, Culture and Eduction, London.

OECD. (2009). The Impact of Culture on Tourism.

OECD. (2014). Tourism and the Creative Economy. OECD Studies on Tourism. http://doi.org/10.1787/9789264207875-en

Ohridska-Olson, R. V., \& Ivanov, S. H. (2010). Creative Tourism Business Model And Its Application In Bulgaria. Cultural Realms, 1-17. Retrieved from

http://papers.ssrn.com/sol3/papers.cfm?abstract_id=1690425\%0Ahtt p://culturalrealms.typepad.com/files/creativetourismbm_article_1_Ir. pdf\%0Ahttp://www.culturalrealms.com/2010/07/the-creative-

tourism-business-model.html

Pappalepore, I., Maitland, R., \& Smith, A. (2010). Exploring Urban Creativity: Visitor Experiences of Spitalfields, London. Tourism Culture \& Communication, 10(3), 217-230. http://doi.org/10.3727/109830410X12910355180946

Pappalepore, I., Maitland, R., \& Smith, A. (2014). Prosuming creative urban areas Evidence from East London. Annals of Tourism Research, 44, 227-240. http://doi.org/10.1016/j.annals.2013.11.001

Pine, J., \& Gilmore, J. (1998). Welcome to the Experience Economy. Harvard Business Review, (July-August), 97-105.

Pöllmann, A. (2013). Intercultural Capital. SAGE Open, 3(2), 215824401348611. http://doi.org/10.1177/2158244013486117

Poon, A. (1993). Tourism, technology and competitive strategies. Wallingford: $\mathrm{CABI}$.

Porter, M. E. (1990). The Competitive Advantage of Nations. Harvard Business Review, 21. http://doi.org/10.1007/978-1-349-11336-1

Potts, J., Cunningham, S., Hartley, J., \& Ormerod, P. (2008). Social network markets: A new definition of the creative industries. Journal of Cultural Economics, 32(3), 167-185. http://doi.org/10.1007/s10824008-9066-y

Prahalad, C. K., \& Ramaswamy, V. (2003). The new frontier of experience innovation. MIT Sloan Management Review, 44(4), 12-18. http://doi.org/10.1371/journal.pone.0015090

Prahalad, C. K., \& Ramaswamy, V. (2004). Co-creation experiences: The next practice in value creation. Journal of Interactive Marketing, 18(3), 5-14. http://doi.org/10.1002/dir.20015

Pratt, A. C. (2008). Creative cities: The cultural industries and the creative class. Geografiska Annaler, Series B: Human Geography, 90(2), 107-117. http://doi.org/10.1111/j.1468-0467.2008.00281.x

Prieur, A., \& Savage, M. (2011). Updating cultural capital theory: A discussion based on studies in Denmark and in Britain. Poetics, 39(6), 566-580. http://doi.org/10.1016/j.poetic.2011.09.002

Raunig, G., Ray, G., \& Wuggenig, U. (2011). Critique of Creativity:
Precarity, Subjectivity and Resistance in the 'Creative Industries.' London: MayFlyBooks

Ravar, A. S., \& lorgulescu, M. (2014). ANALYZING MANAGERS' PERCEPTION OF CREATIVITY IN TOURISM. Network Intelligence Studies, II(2), 255-262.

Rhodes, M. (1961). Analysis of Creativity Can It be Taught? The Phi Delta Kappan, 42, 305-310.

Richards, G. (1996). Skilled consumption and UK ski holidays. Tourism Management, 17(1), 25-34. http://doi.org/10.1016/02615177(96)00097-0

Richards, G. (2003). Turismo creativo: una nueva strategia? In Ortega, E. (ed), Investigación y estrategias turísticas (pp. 107-122). Madrid: Thomson.

Richards, G. (2009). Creative Tourism and Local Development. In R. Wurzburguer, T. Aageson, A. Pattakos, \& S. Pratt (Eds.), A global conversation. How to provide unique creative experiences for travelers worldwide (pp. 78-90). Santa Fe: Sunstone Press.

Richards, G. (2010a). Creative Tourism and Cultural Events. Paper presented at 2nd Forum on UNESCO Creative Cities Network Icheon, Republic of Korea, 21 October, 2010.

Richards, G. (2011). Creativity and tourism. The state of the art. Annals of Tourism Research, 38(4), 1225-1253. http://doi.org/10.1016/j.annals.2011.07.008

Richards, G. (2012). Tourism, Creativity and Creative Industries. Paper presented at the conference Creativity and Creative Industries in Challenging Times, NHTV Breda, November 2012.

Richards, G. (2013a). Creating relational tourism through exchange. Paper presented at the ATLAS Annual Conference, Malta, November 2013.

Richards, G. (2013b). Creativity and tourism in the city. Current Issues in Tourism, 17(2), 119-144. http://doi.org/10.1080/13683500.2013.783794

Richards, G. (2013c). Tourism development trajectories: From culture to creativity? In M. Smith \& G. Richards (Eds.), The Routledge Handbook of Cultural Tourism (1st ed., pp. 330-331). London: Routledge.

Richards, G. (2015a). Creative Tourism: New Opportunities for Destinations Worldwide? Presentation at the World Travel Market Conference on 'Creative Tourism: All that you need to know about this growing sector', November 3rd 2015.

Richards, G. (2015b). Festivals in the network society. In: C. Newbold, C. Maughan, J. Jordan \& F. Bianchini (eds), Focus on festivals contemporary European case studies and perspectives (pp. 245-254). Oxford: Goodfellow Publishers Ltd.

Richards, G. (2016). Co-designing experiences with consumers: the case of creative tourism. Input for a workshop on experience design, Troms $\emptyset$, 27 May 2016.

Richards, G., \& Marques, L. (2012). Exploring Creative Tourism : Editors Introduction. Journal of Tourism Consumption and Practice, 4(2), 1-11. Richards, G., \& Raymond, C. (2000). Creative tourism. ATLAS News, 23, 16-20.

Richards, G., \& Wilson, J. (2006). Developing creativity in tourist experiences: A solution to the serial reproduction of culture ? Tourism Management, 27(6), 1209-1223. http://doi.org/10.1016/j.tourman.2005.06.002

Richards, G., \& Wilson, J. (2007). Tourism, Creativity and Development. London: Routledge. http://doi.org/10.4324/9780203933695

Rihova, I. (2013). Customer-to-customer co-creation of value in the context of festivals. Phd Thesis Retrieved 12 July 2018 from http://eprints.bournemouth.ac.uk/21072/1/Rihova,Ivana_PhD_2013.p df

Salman, D., \& Uygur, D. (2010). Creative tourism and emotional labor: an investigatory model of possible interactions. International Journal of Culture, Tourism and Hospitality Research, 4(3), 186-197. http://doi.org/10.1108/17506181011067583

Scitovsky, T. (1972). What's wrong with the arts is what's wrong with 
society. The American Economic Review, 62(1/2), 62-69.

Smith, M. (2016). Issues in Cultural Tourism Studies. New York: Routledge.

Tan, S., Kung, S., \& Luh, D. (2013). A model of "creative experience" in creative tourism. Annals of Tourism Research, 41, 153-174. http://doi.org/10.1016/j.annals.2012.12.002

Tan, S., Luh, D., \& Kung, S. (2014). A taxonomy of creative tourists in creative tourism. Tourism Management, 42, 248-259. http://doi.org/10.1016/j.tourman.2013.11.008

Thompson, C, J. (2000). Postmodern consumer goals made easy. In S. Ratneshwar, D. G. Mick, \& C. Huffmann (Eds.), The Why of Consumption Contemporary perspectives on consumer motives, goals, and desires (pp. 118-137). New York: Routledge.

UNESCO. (2006). Discussion Report of the Planning Meeting for 2008 International Conference on Creative Tourism. Santa Fe, New Mexico.

Virginija, J. (2016). Interaction between Cultural/Creative Tourism and Tourism/Cultural Heritage Industries. In L. Butowski (Ed.), Tourism From Empirical Research Towards Practical Application (pp. 137-157). http://doi.org/10.5772/61385

Willett, J. (2009). Cornwall's Experience of the Experience Economy. Longitudinal Impacts, 1-15.

Received: 12 June 2018

Revisions required: 20 September 2018

Accepted: 10 November 2018 